\title{
Teachers as Educational Innovators in Inquiry-Based Science Teaching and Learning
}

\section{Loukomies, Anni}

Springer

2018

Loukomies , A , Juuti , K \& Lavonen , J 2018 , Teachers as Educational Innovators in Inquiry-Based Science Teaching and Learning . in O E Tsivitanidou , P Gray , E Rybska , L Louca \& C P Constantinou (eds), Professional Development for Inquiry-Based Science Teaching and Learning . Contributions from Science Education Research, vol. 5 , Springer , Cham , pp. 185-201 . https://doi.org/10.1007/978-3-319-91406-0_10

http://hdl.handle.net/10138/315653

https://doi.org/10.1007/978-3-319-91406-0_10

acceptedVersion

Downloaded from Helda, University of Helsinki institutional repository.

This is an electronic reprint of the original article.

This reprint may differ from the original in pagination and typographic detail.

Please cite the original version. 
Loukomies, A., Juuti, K., \& Lavonen, J. (2018). Teachers as

Educational Innovators in Inquiry-Based Science Teaching and

Learning. In Tsivitanidou, O., Gray, P., Rybska, E., Louca, L. \&

Constantinou, C. (eds.), Professional Development for Inquiry-

Based Science Teaching and Learning (pp. 185 - 201). Springer

\title{
Teachers as Educational Innovators in Inquiry- Based Science Teaching and Learning
}

\author{
Anni Loukomies, Kalle Juuti \& Jari Lavonen
}

\begin{abstract}
This chapter describes inquiry based science teaching and learning (IBST/L) pilots designed by teachers during a professional development programme. There is research-based evidence that IBSL/T may promote students' learning and their motivation to learn science, and therefore it is beneficial to familiarize the teachers with this approach. Building on teachers' existing expertise in designing their teaching, the programme introduced theoretical aspects of the IBST/L approach and its research-based benefits for students' motivation, interest and science learning. The course aimed to support teachers as educational innovators in the process of designing and testing IBST/L pilots, during which they collaboratively reflected on and revised their existing practices. The data of this piece of research consists of the teachers' poster presentations of their IBST/L pilots and a video recording of the reflection session. The content analysis revealed that the pilots' structure seemed traditional but encompassed some IBST/L features. It is concluded that teacher educators need to understand teachers' views of IBST/L in order to more effectively support planning and reflection.
\end{abstract}

Keywords: professional development, student motivation, inquiry based science teaching and learning (IBST/L), educational innovation, reflection

\section{Introduction}

This chapter introduces a professional development program (PDP) for science teachers. The PDP was built on the principle of acknowledging teachers' expertise in designing their teaching. The participants were provided with a theoretical grounding in inquiry-based science teaching and learning (IBST/L) and its benefits for students' motivation, interest and learning science-in other words, a rationale for employing the IBST/L approach. The PDP sought to support teachers in the process of collaboratively reflecting on their existing practices and revising them with a view to employing the principles of IBST/L in teaching. In what 
follows, the research-based understanding of teachers' expertise, the meaning of IBST/L and its potential to promote pupils' and students' motivation, interest and learning are introduced. As what follows, the application of these IBST/L ideas in a PDP that employed reflection activities as a means of recognising and revising the teaching practices of participating teachers are described. Then the results of the data analysis are presented. The data consists of teachers' poster presentations of their IBST/L pilots and video-recorded reflection sessions during the PDP. Finally, the potential and challenges of organising a PDP based on such an approach are discussed and, more specifically, how this approach served to promote IBST/L in the participants' teaching practices.

\section{Inquiry Based Teaching and Learning $(I B S T / L)$ and professional development}

The aims of school science encompass more than learning science concepts or learning to perform scientific experiments. It is essential, of course, to understand concepts and the relations between them, but the scope and the aims of learning and teaching science are more comprehensive, encompassing scientific thinking, a coherent worldview and students' development as learners. As elsewhere, this is the situation in Finland. Along with the understanding of scientific concepts, the Finnish national science curriculum that takes effect from 2016 (FNBE, 2014) introduces the following aims, among others, for science learning: establish the motivation to learn science and the ability to take responsibility for one's learning; set aims for learning; think critically and in a scientific way; plan, conduct and communicate scientific investigations in a collaborative manner; and use models and concepts to explain scientific phenomena. The new science curriculum also emphasises practices that are important in engineering, such as the use of creativity in science- and technology-related projects. At a broader level, students are expected to develop a coherent and scientifically argued view of the world, as well as an understanding of how scientific knowledge is generated. They are also expected to act responsibly in relation to their environment and to make reasonable decisions based on scientific thinking.

Beyond Finland, the active renewal of science curricula is in evidence across the world. For example, in the US, the Next Generation Science Standards (NGSS) that frame K-12 science education also aspire to students' comprehensive understanding. These standards introduce the idea of science practices that encompass a variety of skills and knowledge related to the actual behaviours of scientists. In particular, the standards emphasise that science practices should not be reduced to traditional experimental investigations but should also encompass other significant aspects of science, such as evaluation, evidence-based argumentation and communication.

In recent science education research, aims and characteristics of the kind described above are typically referred to as inquiry-based. However, it has also been argued that this term has been interpreted in too many different ways by the science 
education community in the context of science education (NRC, 2012, p. 30). Given this confusion about what is specifically meant by inquiry in the first place, we have adopted the framework constructed by Minner, Levy and Century (2010), both for its soundness and because it emphasises issues considered central in the Finnish National Core Curriculum for Science Education.

Minner, Levy and Century (2010) constructed this framework following their review of 138 studies of inquiry instruction, from which they extracted the following six common characteristics: 1) presence of science content; 2) student engagement with science content; 3) student responsibility for learning, 4) active thinking by students; 5) student motivation and 6) an investigation cycle that encompasses formulating the question to be investigated, designing the investigation, collecting and organising data, drawing conclusions, and communicating the investigations. Items 3, 4 and 5 should occur within at least one of the components of the investigation cycle. These essential process skills are associated with the scientific method and understanding of 'the nature of science' that Anderson (2007) includes in his definition of inquiry. Anderson (2007) also specifies that student engagement with science content encompasses epistemologically authentic procedures such as reasoning, asking questions and designing experiments, and he further emphasises the role of social interaction and collaboration.

The definition of inquiry described above, that is based on the work of Minner et al. (2010) and Anderson (2007), is what was passed on to the teachers who were participating the PDP. It is in line with the one introduced in the Chapter 1 of this volume. In Chapter 1 it is emphasised that 'inquiry involves a degree of autonomy or responsibility for learning' (pp. XX, this volume). When organising the PDP, the fundamental principle was to respect the participant teachers' autonomy during their planning and designing process, and encourage them to further offer the same autonomy to their pupils. In Chapter 1 (pp. XX) and in the definition above, also other aspects of inquiry are emphasised besides those related to motivation, responsibility and active thinking, but in this chapter, the focus is on these three aspects. Understanding the nature of science and the scientific processes may be in the focus in future research.

Promoting motivation is important because there is evidence that, whatever one's theoretical perspective, high-quality motivation yields better learning outcomes (Guay, Ratelle, \& Chanal, 2008; Niemiec, \& Ryan, 2009; Reeve \& Halusic, 2009) and better mental well-being (Vasalampi, Salmela-Aro, \& Nurmi, 2009; Tuominen-Soini, 2012). Teachers play a key role in supporting students motivation and interest, and therefore the basic mechanisms of generating and maintaining motivation in the contexts of the Self-Determination Theory and Expectancy-Value Theory (Ryan \& Deci, 2002; Eccles, 2005) were introduced to the participants.

In Finland, teachers are valued as experts in curriculum development, teaching and assessment at all school levels. At the same time, however, Finnish science teachers tend to be pedagogically conservative, commonly favouring direct teaching of large groups of students (Norris, Asplund, MacDonald, Schostak, \& 
Zamorski, 1996; Juuti, Lavonen, Uitto, Byman, \& Meisalo, 2010). It is often quite difficult to convince teachers to change their teaching practices, and this is one of the crucial issues in teachers' professional development (e.g. Donovan, 1999). However, Yeager and Walton (2011) suggest in their review that small-scale interventions that are firmly grounded on relevant theories but also take into account the characteristics of the context in which they are about to take place, may have large-scale and lasting effects. They stressed that the focus of these interventions is not on learning the content but changing the participants' mind-sets through using persuasive methods that are grounded on relevant research and getting the participants to communicate the new ideas.

\section{Teachers as educational innovators and reflective professionals}

Finnish teachers are considered to be professionals with high-level subject knowledge, pedagogical content knowledge and general pedagogical knowledge. Teachers are expected to have a good understanding of student assessment and curriculum development. As professionals, teachers must also exhibit high-level communication skills and moral knowledge, as well as the skills needed for professional development (Krzywacki, Lavonen, \& Juuti, 2015). Instead of reading and following detailed descriptions of lesson plans, teachers should design their own applications of newly introduced pedagogical approaches. The vision of teachers from Keith Sawyer (2004) is adopted in this research. Sawyer insisted that '[T] eachers are knowledgeable and expert professionals and are granted creative autonomy to improvise in their classroom' (p. 18). To complement this view, Lavonen, Juuti, Aksela and Meisalo (2006) identified empowerment and communication as 'optimal features' for the professional development projects of Finnish science teachers. By empowerment they meant that, in their professional development practices, teacher educators must consider teachers as professionals who make independent decisions about their own teaching. It follows that 'teachers should be guided in their planning and evaluation of small teaching experiments that are then implemented in their schools together with the assistance of other teachers' (Lavonen, Juuti, Aksela, \& Meisalo, 2006, p. 170). Communication aspects were seen to include optimal pace and creative atmosphere.

Taken together, these two 'optimal features' emphasise that PDPs cannot be designed as 'scripts' for teachers to follow. The combination of lectures and formal and informal small-group activities in a PDP must be sufficiently flexible to enable teacher educators to accommodate participant teachers' reactions, with time allocated for the development of ideas. As argued by Penuel et al. (2007), offering participants time and support to plan their interventions is important for integrating the new course content into their teaching practice. Lavonen et al. (2006) emphasised that teacher professional development projects must allow room for the free generation of ideas and for positive feedback on all ideas. The atmosphere must 
be safe and supportive to encourage teachers to take risks despite the possible 'failure' of teaching experiments. Juuti, Lavonen, Aksela and Meisalo (2009) highlighted the importance of providing opportunities for informal communication in a supportive atmosphere.

According to Sawyer (2004), a scripted curriculum fails to access either teachers' creativity or their subject knowledge. Introducing the metaphor 'teaching as improvisation', Sawyer makes an analogy between classroom discourse and improvisational theatre, where actors work without scripts. Instead, they have only broad structures or 'games' that they play. Sawyer summarises sociocultural and social constructivist theory as implying, in a sense, that effective teaching must be improvisational; otherwise, students cannot co-construct their own knowledge. A classroom where the teacher controls the discussion is not improvisational. Rather, improvisational classrooms are collaborative, drawing on constructivist and inquiry-based methods. 'In improvising, the teacher creates a dialogue with the students, giving them freedom to creatively construct their own knowledge' (Sawyer, 2004, p. 14). To support this construction process, teachers need to offer disciplinary tools for students to refine their thinking about science content (Jurow \& McFadden, 2011).

In helping teachers to develop their teaching practices, teaching experiences need to be reflected upon. Reflective thinking is an essential aspect of teachers' professional development, as it connects beliefs and practice (MansvelderLongayroux, Beijaard, \& Verloop, 2007; Linn, 2009). Through reflection on actions, an experience becomes knowledge, and collaborative reflection with peer teachers and researchers creates new knowledge. As belief change follows changes in practice (reflection on action), teachers should be guided to monitor their practice and to reflect their new experiences. Reflection and learning from different perspectives can be facilitated through sharing within collaborative discussions. To encourage teachers to integrate educational innovation and research into their practices and beliefs, it is important to organise activities that can support collaboration and reflection (Uhrich, 2009). According to Rodgers (2002), reflection depends on attitudes that value personal and intellectual growth, both in oneself and in others (p. 845). The PDP approach described here sustains such attitudes by appreciating teachers as professionals who design their own work rather than as passive recipients of knowledge.

\section{Research Questions}

When designing the workshops, the aim was to promote participating teachers' professional development and growth. The aim was also to facilitate teachers' adoption of theory-based aspects of inquiry, supported by an understanding of its benefits for students' motivation and learning. Finally, the aim was to help them to adopt features of IBST/L in their own teaching, focusing on 
teaching strategies rather than on science content. In planning, the following aspects were taken into account: (1) Participating teachers are expected to be experts who autonomously design and develop their own teaching. Teachers and researchers appreciate each other's expertise; while teachers are experts on praxis (involving, for example, knowledge of their students and groups), researchers are experts on theory. (2) In the contact meetings, researchers made brief introductory presentations on the principles and other aspects of IBST/L. Associated collaborative discussions assisted understanding of how the ideas presented would be of benefit in participants' classes. (3) The IBST/L pilots were planned to be designed and implemented by teachers in their classes independently and then presented and reflected in a PDP group session.

The focus of this research is not on the students' achievements or the development of their motivation, but on how the participating teachers reported having implemented the ideas presented during the course. The implementations are evaluated with respect to the IBST/L frame suggested by Minner et al. (2010). The research questions are:

1. What were the teachers' inquiry-based science teaching and learning (IBST/L) pilots like?

2. How the do the IBST/L aspects suggested by Minner \& al. (2010) (support to students' active thinking, students' responsibility and students' motivation) appear in the teachers' pilots according to what the teachers presented?

\section{Method}

\section{Participants and outline of the Professional Development Programme (PDP)}

In Finland, teachers have access to a wide variety of professional development courses, but participation in professional development is not compulsory. There was an open call to participate this PDP. Six lower secondary school physics and chemistry teachers participated in the PDP. All of them had major in either physics or chemistry and several years of teaching experience. All the participants were female, ranging in age from about thirty to sixty years.

Participating teachers could choose the scientific content they wished to work with from the school curriculum, and they were then asked to apply the principles of IBST/L in teaching the chosen content. Participants were introduced with the basic ideas of inquiry, the theoretical connection between inquiry teaching and motivation, and the diverse possibilities for applying IBST/L. To maximize 
opportunities for collaborative discussion, the PDP was designed to be short and intensive (Sawyer, 2004; 2006; Yeager \& Walton, 2011). The PDP was therefore run as two two-day workshops. Between the workshops, each teacher implemented their IBST/L pilot in their own classroom.

During the first workshop, teachers planned their own pilots, which were then discussed collaboratively. It was agreed that instruction should follow the principles of IBST/L, with special emphasis to be placed on the engagement phase. The pilots were to consist of one or two 45-75 minute lessons. Planning activity took place in pairs, but there was also a lot of ongoing collaborative discussion between pairs. During the workshop, the basic ideas of IBST/L were collaboratively discussed to encourage participants to reflect on their pilots. Each participant made a brief presentation on their own IBST/L pilot, followed by collaboratively reflection. As short-term workshop-based programmes have been criticised for not being effective (Lumpe, 2007), it was decided to compensate for the brevity of the PDP intervention by emphasising effective feedback, cooperation, collegiality, practice-oriented staff development, a culture of shared beliefs and relationships (cf. Lumpe, 2007; Kim, Lavonen, Juuti, Holbrook, \& Rannikmäe, 2013).

After the first workshop, the teachers went back to their schools and implemented their plans. In the second workshop, the teachers presented the implementations of their pilots, one after another. After each presentation, the implementation of the pilot was discussed. This workshop took four hours and it was video recorded.

\section{Data Collection and Analysis}

The research questions are answered based on data that consists of teachers' posters of their pilots and a four-hour collaborative teacher presentations and reflective discussion that was video-recorded. The analysis of the data followed principles of theory driven content analysis (Patton, 2002). The analysis categories in the analysis frame deductively emerged from theories, in more detail from the conceptualization of IBST/L constructed by Minner \& al. (2010) and theories conceptualizing the components of motivation, in more detail the expectancy-value theory (e.g. Eccles, 2005) and the self-determination theory (e.g Ryan \& Deci, 2002). According to the frame suggested by Minner et al. (2010), an instruction was classified as inquiry if at least one of the phases of instruction included student responsibility, student active thinking and support for motivation. In our version, one minor revision was made with respect to the motivation subcategories. Minner et al.'s (2010) indices of motivation included students' expressions of interest, involvement, curiosity, enthusiasm, perseverance, eagerness, focus, concentration and pride. Many of these factors are closely related to intrinsic forms of student motivation and are therefore difficult to track for data such as poster presentation. For that reason, we enriched the approach by drawing on the motivation 
components introduced in the expectancy-value theory (Eccles, 2005) and the selfdetermination theory (Ryan \& Deci, 2002).

Aspects related to the mentioned theories were extracted from the pilot posters and from those parts of the reflection discussion that concerned a certain pilot. These aspects were then categorized into the categories student responsibility, student active thinking and support for motivation. The motivation category consisted of subcategories Intrinsic value/interest (IN), Attainment value/significance (AT), Utility value (UT) (Eccles, 2005), Support for Autonomy (AU), Support for Competence (CO) and Support for Social Relatedness (SR) (Ryan \& Deci, 2002).

Each pilot was analyzed using the template introduced in Table 1. In Table 1 , the analysis of the pilot 1 . is presented as an example of how the analysis was conducted. After the extraction the IBST/L aspects of each pilot and categorization of them, a short descriptions was written of each pilot. Then a more detailed description was written of the IBST/L features related to motivation, active thinking and responsibility. The phase of the procedure in which the IBST/L features occurred was noted, and the course of the lesson was compared to the phases of inquiry instruction proposed by Minner et al. (2010) (formulating the question to be investigated, designing the investigation, collecting and organising data, drawing conclusions and communicating the results of the investigation).

The content of each pilot (based on the poster and teacher presentation) is summarized below, along with a short description of its inquiry aspects. As this chapter focuses on the inquiry aspects of the pilots, their effect on students' motivation or learning are not evaluated here. It must be emphasized that the researchers were not present when the teachers implemented their pilots, but the analysis is conducted based on what the teachers reported about their implementations. For the purposes of the study, only five teachers' ISBT/L pilots were analyzed; one teacher's plan was omitted from the analysis because of practical problems on the school side during implementation.

Table 1. Analysis tool for the IBST/L pilots 


\section{Teacher No. 1}

\begin{tabular}{|c|c|}
\hline Science content & Physics, simple machines \\
\hline Type of Engagement & $\begin{array}{l}\text { Using Lego characters, students were required to construct a comic } \\
\text { strip related to the topic Simple machines. They designed the storyline, } \\
\text { constructed the scene and took the photos needed for the comic strip. } \\
\text { Students also built the machines they needed to meet the physics } \\
\text { content required by the instruction. The instruction was published in a } \\
\text { web-based learning environment. At the end of the process, students } \\
\text { commented each other's work. }\end{array}$ \\
\hline $\begin{array}{l}\text { Motivation } \\
\text {-Autonomy (AU) } \\
\text {-Competence (CO) } \\
\text {-Social Relatedness (SR) } \\
\text {-Intrinsic value/interest } \\
\text { (IN) } \\
\text {-Attainment } \\
\text { value/significance (AT) } \\
\text {-Utility value (UT) }\end{array}$ & $\begin{array}{l}\text { AU, SR, IN: Working on the comic strip } \\
\text { AU, SR: Building the machines needed for the comic strip } \\
\text { AU: Deciding on the length of the comics } \\
\text { SR, AU: Choosing the groups } \\
\text { AU, SR: Setting the scene } \\
\text { AU, SR: Conducting the experiments autonomously } \\
\text { AU: Deciding on the working order } \\
\text { AU: Deciding on the story } \\
\text { AU: Deciding on the software } \\
\text { AU: Deciding on the allocation of tasks } \\
\text { IN: Drawing a comic strip } \\
\text { IN: Using Lego characters } \\
\text { IN: Using language that fits the students' world } \\
\text { AU: Working on a web-based learning environment } \\
\text { IN, AU: Working with students' own cameras } \\
\text { UT: Working on a web-based learning environment } \\
\text { CO, AU: Finalising output autonomously } \\
\text { CO: Using relevant physics concepts } \\
\text { CO: Providing feedback for others in the web-based learning environment } \\
\text { CO: Commenting on others' work } \\
\text { UT: Using the web-based learning environment } \\
\text { UT: Studying a topic from the curriculum }\end{array}$ \\
\hline Responsibility & $\begin{array}{l}\text { Working on the comic strip } \\
\text { Working in a web-based learning environment } \\
\text { Planning the comic strip } \\
\text { Deciding on roles within the group } \\
\text { Choosing the groups } \\
\text { Deciding on task allocation } \\
\text { Deciding on software } \\
\text { Finalising the comic strip } \\
\text { Providing feedback to other groups in the web-based learning environment }\end{array}$ \\
\hline
\end{tabular}




$\begin{array}{ll}\text { Active thinking } & \begin{array}{l}\text { Interpreting the instructions provided in the web-based learning } \\ \text { environment }\end{array} \\ \text { Recalling one's own experiences of simple machines } & \text { Working on the comic strip } \\ \text { Working in a web-based learning environment } & \text { Building the machines } \\ \text { Broadening the context beyond physics and creating a story } \\ \text { Setting the scene and conducting experiments autonomously Deciding on } \\ \text { the working order } \\ \text { Using relevant physics concepts }\end{array}$




\section{Results}

\section{Teacher 1}

The context of this pilot was mechanics or, more precisely, simple machines. The pilot opened with a framework story, set in a world of Lego policemen and thieves. Students designed the scene for the story and photographed it. They had to consider how the characters' tasks were facilitated by certain simple machines, and they then had to translate the facts into explicit mathematical forms. The students worked in groups; the teacher assigned specific roles to all group members. The required output was a comic strip, constructed from their own photos of the scenes and continuing the story introduced by the teacher. The essential principles of simple machines were to appear in the comic, and these outputs were to be uploaded to a web-based learning environment for further collaborative elaboration. The comic strips served as a substitute for the traditional lab report. The teacher reported that some of the students did better than usual, and she was astonished at the students' specific use of physics concepts.

Students' responsibility for learning: Teacher $\# 1$ allowed students to make decisions about groups, task allocation within the groups, the software to be used, the storyline behind the comic strip, and how the scene for the story would be built. Students built the machines they needed to match the required physics content. They worked autonomously in groups according to the instructions published in the web-based learning environment. They also commented on each other's work.

Students' active thinking: Teacher \#1 required the students to interpret the web-based instructions independently. Students also needed to plan the scenes of their comics and to consider how the physics content was to be presented. They also needed to decide which physics concepts were needed.

Students' motivation: As well as motivation-related aspects emphasising students' responsibility, their feelings of social relatedness were supported by allowing them to work in groups. This teacher chose a framework story with Lego characters that contained intrinsic value. According to the teacher, the students also managed the task well and so increased their feelings of competence. Working in a web-based learning environment has utility value, as students learn skills that may be of subsequent use. However, there was little support for students' attainment value - the feeling that they are doing something significant — as the topic was not considered from any wider perspective beyond the classroom. Simple machines is also a topic on the primary school science curriculum in Finland, and lower secondary students might, for instance, have been asked to construct animations to be used in primary science teaching.

Nevertheless, of the four pilots designed during the PDP, this was the most multi-faceted and allowed most space for the students' creativity while at the same time highlighting disciplinary learning. The structure of this pilot was loosely compatible with the procedure proposed by Minner et al. (2010), as it encompassed the students' own design and encouraged them to implement the design and 
communicate the results. The major deficiencies were that the project did not begin with a research question, and no experiments were conducted.

\section{Teachers 2 and 3}

These two teachers worked at the same school and therefore decided to plan a teaching sequence together. Only one teacher presented their pilot, which again involved the use of comic strips. The content sequences chosen by both teachers concerned nutrients. At the beginning of the pilot, the teachers first told the students about some of their own experiences related to nutrients, explaining how they taught nutrition, how they implemented this knowledge in their everyday lives, and how they intended to combine the science content with the students' everyday experiences. They also discussed the typical structure of a three-panel comic strip and showed some examples. Students read the content of their own textbooks, and the teacher gave instructions how to transform the text into a comic strip. The teachers also gave instructions about the working schedule, group formation and specific tasks within the group. The students decided on the topic they wished to deal with and then allocated tasks within the group. The comics were constructed and the work was evaluated.

Student responsibility: Teachers chose the groups but allowed the students to allocate tasks within the group. Students were also allowed to choose their perspective within the limits of the topic of the lesson. Teacher \#2 said it was usual for her to tell students about her own experiences, and in that sense at least, this lesson was no exception. In mid-process, the students modified the instruction, and the teacher allowed that to happen, as the students were eager to discuss the topic.

Active thinking: Students needed to consider how they would convert the text into a comic strip, and to decide on the essential aspects of the text to be presented in a simple series of pictures. Students also had their own roles within the group, and they needed to decide what tasks were related to each role.

Motivation: Students' feelings of social relatedness were supported by allowing them to work in groups. The drawing task was interesting for the most of the students and could be said to contain intrinsic value. It can also be said that the topic (Nutrients) contains some utility value, as it may benefit students' health in later life to have accurate information about the topic. However, from the IBST/L perspective, the structure of this lesson seemed quite traditional, and it was not compatible with the IBST/L procedure proposed by Minner et al. (2010). There was no actual research question to begin the procedure, nor did it begin from students' questions. Additionally, the lesson did not include any experimental work or data collection of any kind. The teachers made all the main decisions, as is readily apparent from the pilot poster, in which almost all sentences begin with phrases such as 'The teacher described the topic...', 'The teacher divided the students into groups...' and 'The teacher assigned topics to the groups...'. Clearly, not many decisions were left to the students, and there was no attempt to emphasise the meaningfulness of the task to increase attainment value. 


\section{Teacher 4}

The scientific content of this pilot related to magnetism. The teacher decided to combine fictional and personal stories as well as concept maps and essay writing in her pilot sequence. Opening with a video of Superman and a magnetic telescope, she described her own experience of visiting a lab with a powerful magnet. Within the groups, students discussed what was fact and what was fiction in the film. According to the teacher, this was a very difficult task for the students. The experimental work relating to magnetism was conducted according to online video instructions. Students elaborated further on the topic by constructing concept maps, using CmapTools software. Their concept maps were based on the textbook, supported by facilitating questions. As homework, the students wrote essays based on their concept maps.

Student responsibility: Teacher 4 said that her students were not allowed to decide about anything, but they were expected to autonomously regulate their activities in constructing concept maps and writing essays. Their responsibility was emphasised in the essay-writing phase, and to prevent them from copying and pasting, the teacher asked them to write the essays with paper and pen.

Active thinking: In producing their concept maps and essays, students had to actively process their knowledge constructions. They also needed to consider how the web-based inquiry instruction was to be interpreted.

Motivation: Teacher 4 included many interest-awakening situational features in the pilot, as students watched videos and heard stories about interesting occasions. This teacher found it very easy to tell spontaneous stories but had more difficulty telling something that had been decided beforehand. She included stories of many kinds in her pilot - a fictional story on video and her own experiences of the same topic. However, when constructing the poster about her pilot, she framed motivation as an isolated part of the lesson; in fact, what she thought of as motivation was merely awakening situational interest.

Although this pilot included a range of teaching methods and encompassed experimental work, and although the students were required to work autonomously according to the teacher's instruction, the approach seemed quite traditional. After awakening interest, the teacher directed students to complete experimental work according to the instructions before constructing a concept map and writing an essay. The topic's connection to real world problems was not emphasised, and the students were not allowed to decide their own perspective or to construct their own questions.

\section{Teacher 5}

The scientific content of this pilot related to nutrients. The lesson opened with a discussion of the students' own experiences of carbohydrates. After that students collaborated in constructing concept maps with the CmapTools software, 
with each group outputting one shared concept map. Experimental work related to the same topic was also included in the lesson. As a homework output, students wrote brief reports on the experiment.

Student responsibility: Teacher 5 complained that she encountered a lot of practical difficulties in implementing her pilot. She had originally planned to organise the groups herself but then decided to leave this to the students themselves. The topic and experimental task were decided by the teacher, but other decisions were left to the students, such as the substances they chose to investigate. The students worked autonomously to produce reports on their experiments, and they constructed concept maps in groups. The teacher also encouraged students to describe their own experiences.

Active thinking: Students needed to actively process their knowledge constructions when producing concept maps, and they were active in drawing conclusions.

Motivation: As well as being given responsibility, students worked with a topic that the teacher believed would be of interest to them. As knowledge of nutrients may be beneficial in later life and outside school, it can be said that the pilot had some utility value. The students also worked in groups; according to the SDT, this should promote their feelings of social relatedness and support their motivation.

Nevertheless, referring again to the essential features of IBST/L, this pilot can be said to have followed a traditional structure rather than the structure of an IBST/L lesson as proposed by Minner et al. (2010). From the beginning of the lesson, the teacher was pulling the strings, and no space was left for the students' own questions or fields of interest. The topic was not connected to the students' own lives, and so the attainment and utility value of the activities was not emphasised. In terms of Minner et al.'s (2010) framework, the nutritional content of food and issues such as sugar concentration may have invited more open investigations. For example, the students could have examined what they had eaten during a certain period and then reviewed the composition of their diet.

In summary, the four designed pilots can be described as quite traditional and teacher-centred. The teachers took responsibility for offering students adequate support and structure for their work, but a shared characteristic of these pilots was that little was left for students to decide. None of the pilots started with the students' questions; all were related to scientific content, but the teachers emphasised concepts. All the pilots contained some physical activities, in the form of experimental work, concept maps, comic strips or PowerPoint presentations. The motivational potential of these pilots related mainly to supporting students' autonomy by allowing them to decide something that was related to their work; supporting students' social relatedness by allowing them to work in pairs or groups; and supporting intrinsic value (interest and enjoyment) mainly in terms of situational interest. Utility value was supported by choosing important topics from the curriculum but not from the point of view of the students' own lives and environment. The feeling of competence was not systematically supported-for example, there was no procedure for evaluating the work and giving feedback to peers or evaluating one's own work. Also, missing from all the pilots was any true 
support for attainment value - the feeling of doing something significant related to students' own lives or environment. With more support for attainment value, students' feeling of participation could also have been increased.

\section{Discussion}

In Chapter 1 of this volume (pp. XX) a question was raised: How to encourage sufficient and effective inquiry-based science teaching of good quality? In this piece of research, this question was approached from two perspectives. First the idea was welcomed that a relevant way to promote change in science classes is to take the teachers' autonomy with respect to their teaching as a starting point. The central inquiry principle, namely fostering autonomy and responsibility, was chosen as an approach when the teachers were guided in their planning process. Second, the PDP was strongly theory based. This principle was realized at two levels. The PDP itself was designed according to research based principles of IBST/L and motivation. Furthermore, the content of the PDP was also based on research based knowledge on motivation and student engagement. To sum up, the aim was to promote the effectiveness of the PDP by fostering the participant teachers' autonomy. Further, the quality of the teachers' IBST/L pilots was promoted through offering them a sound theoretical basis how to support their students' engagement.

The teachers' pilots reflected their understanding of the IBST/L approach as introduced during the contact meetings. The pilots varied according to how teachers interpreted the content of the course. This variety of outcome strengthens the argument of Penuel et al. (2007) that teachers' interpretations of PD activities are important in shaping the effectiveness of those activities, beyond the design of the activities themselves. Each teacher interpreted the task guidelines in a way that fit their own ideas about how best to apply the principles and practices of inquiry teaching. The student groups were all different, which strengthened the improvisational aspect of teaching, even though the lessons were planned beforehand. Sawyer (2004) refers to this effect in arguing that teaching conceived as improvisation emphasises the teacher's creativity in responding to a unique group of students and the unpredictable flow of classroom discussion.

Based on the analysis, it can be suggested that the pilots contained some features of the IBST/L framework proposed by Minner et al. (2010). For instance, all the teachers allowed the students to work in groups, supporting collaboration. Teachers also expected the students to work autonomously and in a responsible way, and they enriched the pilots with material that would engage students' interest. However, the structure of the pilots remained essentially traditional. None of the teachers began the process from the students' own questions, nor did they expand their perspective beyond the classroom or encourage the students to do something that would have been truly significant at some level.

What, then, might account for the lack of inquiry features in these pilots? It is known that teachers' professional development tends to be very slow (Kim, 
Lavonen, Juuti, Holbrook, \& Rannikmäe, 2013; Oliveira, 2010; Nelson, 2009). After reviewing several studies of the effects of short-term interventions, Laursen, Liston, Thiery and Graf (2007) argued that, despite the popularity of the short-term intervention model, there is little convincing or statistically significant evidence of its effectiveness (p. 50). They suggested, however, that participants usually enjoy these occasions. On the other hand, Yeager and Walton (2011) suggest that even brief, the intervention may be effective because it sets into motion recursive social, psychological and intellectual processes in school level and within the individual (Yeager \& Walton, 2011, pp. 286).

Certainly, keeping PD events short is more likely to attract Finnish teachers, as they do not usually have the time, the interest or the financial resources to participate in more extended programmes (Taajamo, Puhakka, \& Välijärvi, 2014), even though they are expected to acquire knowledge of many topics and novel teaching approaches. However, while a shorter PDP cannot change the way teachers teach, our vision of teachers as knowledgeable and expert professionals who are the agents of their own professional development suggests that even a short programme may help to shift their perspective.

In general, teachers tend to view inquiry-based science teaching as laborious, time-consuming and therefore difficult to apply in the classroom (Bybee, 2000). The central principle of the PDP was not to tell teachers how to teach. Instead of asking participants to undertake any extracurricular pilots, they were asked to use the ideas from contact meetings in their teaching, to whatever extent they believed was appropriate for their own classes. The participants were shown that IBST/L is a perspective on teaching and learning rather than a highly structured teaching method, and it involves students' own responsibility for learning, active thinking, and motivation during any lesson (cf. Minner et al. 2010).

During the workshops, the participating teachers' motivation was boosted by supporting their psychological needs (Ryan \& Deci, 2002). The teachers were convinced that they were knowledgeable enough to design IBST/L pilots, and that nobody else could in fact design their teaching (so increasing their feelings of competence). It was also communicated that teachers would be given a lot of autonomy to design their own pilots (feelings of autonomy), and that experiences were shared in a group (feelings of relatedness). Further, in preparing their pilots, the teachers were encouraged to choose a topic that interested them, to design something they could really use (utility value) and that might be of benefit to their students' learning and motivation (attainment value).

To foster the IBST/L approach, it may have been beneficial to include more support for planning, as well as some form of structured evaluation of IBST/L features at some point in the process. However, this model of PDP in which the teachers work in the same manner that they are about to instruct their pupils to work may be implemented even outside Finland.

When they attend a professional development programme, teachers are looking for something new. In a short-term programme, it is important to accept that each teacher is in her or his own phase of the development process. It would be very difficult to design teaching sequences that are suitable for all teachers-this would be likely to prove too revolutionary, or too traditional. The most fruitful 
approach, then, may be to trust teachers and allow them to design their own IBST/L pilots, within a loose framework. During the PDP workshops, the teachers were introduced resources that would enable them to stimulate their own innovation process.

According to Sawyer (2004), 'Implementing creative teaching will require serious, long-term investment in professional development for teachers.... Yet it has the potential to result in brighter, more motivated, and more effective teachers, and to result in students with deeper understanding and improved creative and social skills' (p. 18). It can be argued that the PDP succeeded in awakening participants to the realization that there are alternative ways of organising teaching, and that these may not be much more difficult to organise than traditional methods. The expectation was that, by empowering teachers to design inquiry pilots, their sense of responsibility for their own professional development would be bolstered, and that the effects of this short-term PDP would become long-term by introducing them to some novel approaches. In general, the teachers should be encouraged to adopt novel ways to do what they are doing anyway, not anything extra besides what they are already doing.

The aim here was to evaluate the potential of the professional development model by analysing teachers' presentations of their IBST/L pilots. This research did not explore students' conceptual learning or motivation. However, the potential to promote students' motivation is central to IBST/L instruction, which is why the topic was introduced to participating teachers, and why it is included in the definition of inquiry. Every participant teacher succeeded in designing a pilot with at least some inquiry features. They also valued the collaborative discussions relating to the principles of IBST/L and the meaning of motivation in the classroom, as well as the reflective discussions of each other's IBST/L pilots. 


\section{References}

Andersson, R. D. (2007). Inquiry as an organizing theme for science curricula. In S. K. Abell \& N. G. Lederman (Eds.), Handbook of Research on Science Education (pp. 807-830). London: Lawrence Erlbaum Associates.

Avraamidou, L., \& Osborne, J. (2009). The Role of Narrative in Communicating Science. International Journal of Science Education, 31(12), 1683-1707. doi: $10.1080 / 09500690802380695$

Bransford, J. D., Brown, A. L. \& Cocking, R. C. (Eds.) (2000). How People Learn: Brain, Mind, Experience, and School. Washington, D.C.: National Academy Press.

Bybee, R. W. (2000). Teaching science as inquiry. In J. Minstrell \& E. H. van Zee (Eds.), Inquiring into Inquiry Learning and Teaching in Science (pp. 20-46). Washington, DC: American Association for the Advancement of Science.

Eccles, J. (2005). Subjective task-value and the Eccles et al. model of achievement-related choices. In Elliot, A. J. \& Dweck, C. S. (Eds.) Handbook of Competence and Motivation. New York: Guilford Press.

Fludernik, M. (1996). Towards a 'Natural' Narratology. London \& New York: Routledge.

Gay, G. (2010). Acting on beliefs in teacher education for cultural diversity. Journal of Teacher Education, 61(1-2), 143-152.

Guay, F., Ratelle, C., \& Chanal, J. (2008). Optimal learning in optimal contexts: The role of selfdetermination in education. Canadian Psychology, 49(3), 233-240.

Johnstone, K. (1999). Impro for Storytellers - Theatresports and the Art of Making Things Happen. London: Faber and Faber.

Jurow A. S., and McFadden, L. (2011). Disciplined Improvisation to extend young children's scientific thinking. In Sawyer, R. K. (Ed.), Structure and Improvisation in Creative Teaching (pp. 236-251). Cambridge: Cambridge University Press.

Juuti, K., \& Lavonen, J. (2006). Design-Based Research in Science Education. Nordina 3(1), 54 68.

Juuti, K., Lavonen, J., Aksela, M., \& Meisalo, V. (2009). Adoption of ICT in science education: A case study of communication channels in a teachers' professional development project. Eurasia Journal of Mathematics, Science \& Technology Education, 5(2), 103-118.

Kim, M., Lavonen, J., Juuti, K., Holbrook, J., \& Rannikmäe, M. (2013). Teacher's reflection of inquiry teaching in Finland before and during an in-service program: Examination by a progress model of collaborative reflection. International Journal of Science and Mathematics Education, 11(2), 359-383.

Klassen, S. (2010). The Relation of Story Structure to a Model of Conceptual Change in Science Learning. Science \& Education, 19, 305-317. doi: 10.1007/s11191-009-9212-8

Krzywacki, H., Lavonen, J., \& Juuti, K. (2015). There are no effective teachers in Finland-only effective systems and professional teachers. In O.-S. Tan \& W.-C. Liu (Eds.), Teacher Effectiveness: Capacity Building in a Complex Learning Era (pp. 79-103). Andoven: Cengage Learning.

Lavonen, J., Juuti, K., Aksela, M., \& Meisalo, V. (2006). A Professional Development Project for Improving the Use of ICT in Science Teaching. Technology, Pedagogy and Education, 15(2), 159-174.

Linn, M. C. \& Eylon, B.-S. (2006). Science Education: Integrating Views of Learning and Instruction. In P. A. Alexander \& P. H. Winne (Eds.), Handbook of Educational Psychology (2nd ed.) (pp. 511-544). Mahwah, NJ: Lawrence Erlbaum Associates.

Lumpe, A. (2007). Research-based professional development: Teachers engaged in professional learning communities. Journal of Science Teacher Education, 18, 125-128.

Mansvelder-Longayroux, D. D., Beijaard, D., \& Verloop, N. (2007). The portfolio as a tool for stimulating reflection by student teachers. Teaching and Teacher education, 23(1), 47-62. 
Minner, D., Levy, A. \& Century, J. (2010). Inquiry-based science instruction-what is it and does it matter? Journal of Research in Science Teaching, 47, 474-496.

Nelson, T. H. (2009). Teachers' collaborative inquiry and professional growth: Should we be optimistic? Science Education, 93(3), 548-580.

Niemiec, C. P., \& Ryan, R. M. (2009). Autonomy, competence, and relatedness in the classroom. Theory and Research in Education 7(2), 133-144.

NRC (2012). A Framework for K-12 Science Education: Practices, crosscutting concepts, and core ideas. The National Academies Press.

Organisation for Economic Co-operation and Development (2007). PISA 2006: Science competencies for tomorrow's world executive summary. Paris: Organisation for Economic Co-operation and Development. Retrieved from http://www.oecd.org/dataoecd/15/13/39725224.pdf

Patton, M. Q. (2002). Qualitative research \& evaluation methods (3rd edition). Thousand Oaks, CA: Sage.

Reeve, J., \& Halusic, M. (2009). How K-12 teachers can put self-determination theory principles into practice. Theory and Research in Education, 7(2), 145-154.

Rodgers, C. (2002). Defining reflection: Another look at John Dewey and reflective thinking. Teachers College Record, 104(4), 842-856.

Ryan, R. M., \& Deci, E. L. (2002). An overview of self-determination theory: An organismicdialec- tical perspective. In E. L. Deci \& R. M. Ryan (Eds.), Handbook of Self-Determination Research (pp. 3-33). Rochester, NY: University of Rochester Press.

Sawyer, K. (2004). Creative Teaching: Collaborative Discussion as Disciplined Improvisation. Educational Researcher, 33(2), 12-20.

Sawyer, K. (2006). Educating for innovation. Thinking Skills and Creativity, 1, 41-48. doi: $10.1016 / \mathrm{j}$. tsc.2005.08.001

Sawyer, K. (2011) What makes good teaching great? The artful balance of structure and improvisation. In R. K Sawyer (Ed.), Structure and improvisation in creative teaching (pp. $1-$ 24). Cambridge: Cambridge University Press.

Schunk, D. H., Pintrich, P. R., \& Meece, J. L. (2007). Motivation in education. Upper Saddle River, NJ: Pearson Education.

Silvia, P. J. (2008). Interest-The curious emotion. Current Directions in Psychological Science, $17(1), 57-60$.

Taajamo, M., Puhakka,E., \& Välijärvi, J. (2014). Opetuksen ja oppimisen kansainvälinen tutkimus TALIS 2013. Yläkoulun ensituloksia. Opetus- ja kulttuuriministeriön julkaisuja 2014:15.

Tuominen-Soini, H. (2012). Student motivation and well-being : Achievement goal orientation profiles, temporal stability, and academic and socio-emotional outcomes. (Doctoral dissertation). University of Helsinki. Retrieved from http://urn.fi/URN:ISBN:978-952-108201-6

Uhrich, T. A. (2009). The hierarchy of reflective practice in physical education. Reflective Practice, 10(4), 501-512.

Vasalampi, K., Salmela-Aro, K., \& Nurmi, J.-E. (2009). Adolescents' self-concordance, school engagement, and burnout predict their educational trajectories. European Psychologist 14(4), 332-341.

Viljaranta, J., Nurmi, J.-E., Aunola, K., \& Salmela-Aro, K. (2009). The role of task values in adolescents' educational tracks: A person-oriented approach. Journal of Research on Adolescence, 19(4), 786-798.

Yeager, S.D. \& Walton, G. M. (2011). Social-psychological interventions in education: They're not magic. Review of Educational Research, 81, 267-301. 